Received Date : 30-Sep-2013

Revised Date : 01-Apr-2014

Accepted Date : 13-Apr-2014

Article type : Original Article

ORIGINAL ARTICLE

\title{
Life history influences how fire affects genetic diversity in two lizard species
}

Annabel L. Smith ${ }^{1}$, C. Michael Bull ${ }^{2}$, Michael G. Gardner ${ }^{2,3}$, and Don A. Driscoll ${ }^{1}$

1. Australian Research Council Centre of Excellence for Environmental Decisions and the National

Environmental Research Program Environmental Decisions Hub, Fenner School of Environment and

Society, The Australian National University, Fenner Building 141, Canberra ACT 0200, Australia.

2. School of Biological Sciences, Flinders University, GPO Box 2100, Adelaide SA 5001, Australia.

3. Evolutionary Biology Unit, South Australian Museum, North Terrace, Adelaide SA 5000, Australia.

* Author for correspondence: E: annabel.smith@anu.edu.au, P: +612 6125 9339, F: +612 61250757

Running title: Fire effects on lizard genetic diversity

\begin{abstract}
'Fire mosaics' are often maintained in landscapes to promote successional diversity in vegetation with little understanding of how this will affect ecological processes in animal populations such as
\end{abstract}

This article has been accepted for publication and undergone full peer review but has not been through the copyediting, typesetting, pagination and proofreading process, which may lead to differences between this version and the Version of Record. Please cite this article as doi: $10.1111 / \mathrm{mec} .12757$

This article is protected by copyright. All rights reserved. 
dispersal, social organisation and re-establishment. To investigate these processes, we conducted a replicated, spatio-temporal landscape genetics study of two Australian woodland lizard species (Amphibolurus norrisi (Agamidae) and Ctenotus atlas (Scincidae)). Agamids have a more complex social and territory structure than skinks, so fire might have a greater impact on their population structure and thus genetic diversity. Genetic diversity increased with time since fire in C. atlas and decreased with time since fire in $A$. norrisi. For $C$. at/as, this might reflect its increasing population size after fire, but we could not detect increased gene flow that would reduce loss of genetic diversity through genetic drift. Using landscape resistance analyses, we found no evidence that postfire habitat succession or topography affected gene flow in either species and we were unable to distinguish between survival and immigration as modes of post-fire re-establishment. In A. norrisi, we detected female-biased dispersal, likely reflecting its territorial social structure and polygynous mating system. The increased genetic diversity in A. norrisi in recently burnt habitat might reflect a temporary disruption of its territoriality and increased male dispersal, a hypothesis that was supported with a simulation experiment. Our results suggest that the effects of disturbance on genetic diversity will be stronger for species with territorial social organisation.

\section{Keywords}

Biodiversity conservation; dispersal; disturbance; fire regime; landscape genetics; reptile

\section{Introduction}

Fire is a natural driver of ecological dynamics, but modern changes in land use have altered fire regimes in ecosystems around the world (Butz 2009; Regan et al. 2010). Some animal species are threatened by recent increases in the extent and frequency of fire (Lyet et al. 2009; Sanz-Aguilar et al. 2011), while others decline with less frequent fires (Templeton et al. 2011). Fire management

This article is protected by copyright. All rights reserved. 
often combines prescribed burning and fire suppression to maintain 'fire mosaics', assuming that successional diversity in vegetation will benefit biodiversity overall (Parr \& Andersen 2006).

However, there is little understanding of the spatial and temporal scales at which fire mosaics allow animal species to persist in a landscape (Kelly et al. 2012; Nimmo et al. 2013).

Fire, or lack of fire, can fragment suitable habitat for some animal species (Neuwald \& Templeton 2013) by imposing barriers to dispersal (Levy et al. 2010; Prevedello et al. 2010). Extinction risk may be elevated in populations fragmented by fire mosaics through declines in genetic diversity and population fitness (Frankham 1997). This risk may be determined by quantifying gene flow and genetic diversity in animal species across fire mosaics. Other factors that may influence gene flow such as population density (Konvicka et al. 2012), topography (Cushman et al. 2006) and geographic distance (Wright 1943) can be incorporated into landscape genetics analyses, with fire mosaics, to understand the factors influencing genetic structure (Cushman \& Landguth 2010). This approach has shown how fire influences genetic diversity and spatial genetic structure of some animal species (Brown et al. 2013; Schrey et al. 2011a; Spear \& Storfer 2010). For example, in early successional species, limited genetic structure at large spatial scales suggests that high dispersal rates allow rapid colonisation of recently burnt habitats (Pereoglou et al. 2013; Pierson et al. 2013). Investigations in a wider range of taxa and landscapes are needed to help develop generalised models to explain how fire affects genetic diversity in natural populations (Banks et al. 2013).

If fire causes local extinction, dispersal from surrounding unburnt habitat is essential for reestablishment (Holland \& Bennett 2011). Dispersal may be less important if re-establishment is initiated by survivors of the fire (Banks et al. 2011; Peakall \& Lindenmayer 2006). The mode by which animal populations re-establish after fire is largely unknown (Clarke 2008). Genetic studies could fill this knowledge gap and provide guidance for the spatial scales of fire management that allow species persistence in a landscape (Driscoll et al. 2010).

This article is protected by copyright. All rights reserved. 
Displacement following habitat disturbance, such as fire, can alter social and mating systems and thus the genetic structure of animal populations (DiBattista et al. 2011; Schrey et al. 2011b). Areas surrounding burnt habitat could experience increased immigration of displaced animals (Banks et al. 2012). Untangling effects of long term habitat succession from effects of an initial displacement after fire may be difficult with 'snap-shot' space-for-time studies (Driscoll \& Hardy 2005; Porter 1999). Although rarely done, monitoring change in population structure over time more powerfully assesses the impact of fire on animal populations (Driscoll et al. 2010). Combining spatial and temporal sampling approaches may provide an efficient compromise for examining population structure under complex fire regimes.

We used spatio-temporal sampling and landscape genetics analyses to investigate initial and longterm impacts of fire regimes on the population genetic structure of two Australian lizard species (Amphibolurus norrisi (Agamidae) and Ctenotus atlas (Scincidae)). Both are generally more abundant in late successional vegetation and decline in abundance after fire (Driscoll \& Henderson 2008; Driscoll et al. 2012; Smith et al. 2013). However, their post-fire recovery varies regionally, involving factors other than simply time since fire (Driscoll \& Henderson 2008; Driscoll et al. 2012; Smith et al. 2013). To incorporate this regional variation, we replicated our study in four independent landscapes; a necessary but often overlooked approach in landscape genetics (Short Bull et al. 2011). We characterised fire regimes by fire frequency and time since fire, and also investigated effects of population density and topography on gene flow. By comparing the genetic structure of two different lizard species, we sought to provide insights into how different life histories might influence population responses to fire. Fire may have a greater effect on social structure and thus genetic diversity in agamid lizards that have more complex social and territory structure than skinks (Martins 1994; Stamps 1983). We asked four questions (Table 1):

This article is protected by copyright. All rights reserved. 
1. Does spatial variation in fire regime, topography and population density influence gene flow and genetic diversity?

2. Is there an immediate, temporal effect of fire in the landscape on genetic structure?

3. Is post-fire re-establishment facilitated by survivors, or by immigration from unburnt habitat?

4. Can effects of fire on genetic diversity be explained by differences in demographic attributes such as age structure, sex ratio, social and mating system or sex biased dispersal?

\section{Methods}

Study region \& target species

We sampled four conservation reserves on Eyre Peninsula, South Australia (Fig. 1): Hincks Wilderness Area ( $33^{\circ} 45^{\prime} \mathrm{S}, 136^{\circ} 03^{\prime} \mathrm{E} ; 66,658$ ha), Pinkawillinie Conservation Park ( $32^{\circ} 54^{\prime} \mathrm{S}, 135^{\circ} 53^{\prime}$ E; 130,148 ha), Munyaroo Conservation Park ( $33^{\circ} 21^{\prime} \mathrm{S}, 137^{\circ} 12^{\prime} \mathrm{E} ; 20,139$ ha) and Heggaton Conservation Reserve $\left(33^{\circ} 22^{\prime} \mathrm{S}, 136^{\circ} 31^{\prime} \mathrm{E} ; 6,476 \mathrm{ha}\right)$. The region has an average annual rainfall between $296 \mathrm{~mm}$ and $361 \mathrm{~mm}$. The main topographic features are white sand dunes, occurring in large, parabolic fields or longitudinal ridges interspersed by hard, reddish-brown swales (Twidale \& Campbell 1985). The dominant vegetation in all reserves is low $(<6 \mathrm{~m})$ mallee woodland, characterised by multi-stemmed Eucalyptus spp. (E. costata and E. socialis), commonly associated with Melaleuca uncinata, Callitris verrucosa and Triodia irritans (Specht 1972). Large, severe wildfires occur on a 10-100 year time scale, commonly ignited by summer lighting (Bradstock \& Cohn 2002).

Amphibolurus norrisi and C. atlas are both common in mallee of southern Australia (Wilson \& Swan 2010). Amphibolurus norrisi, absent from Pinkawillinie, was sampled from three reserves only (Fig.

This article is protected by copyright. All rights reserved. 
1). With increasing time since fire (TSF), the semi-arboreal $A$. norrisi increases in abundance at Heggaton (Driscoll \& Henderson 2008) but is unaffected at Hincks (Smith et al. 2013). The reason for this regional variation is currently unknown. Ctenotus atlas inhabits Triodia grasses (Pianka 1969) which peak in density approximately 30 years after fire (Haslem et al. 2011). Population recovery after fire in C. atlas is likely driven by variation in rainfall and grazing that interact with fire regimes to affect the distribution and abundance of Triodia spp. (Driscoll et al. 2012; Nimmo et al. 2012). Home range sizes in A. norrisi range between 0.13 and 2.03 ha (South 2010) and C. atlas can move on average $6 \mathrm{~m}$ per day (Heffernan 2008). Five other Ctenotus species have mean recapture distances of 7-27 m (Read 1998). Agamid lizards often defend territories and have polygynous mating systems while such complex social structure is less common in skinks (Griffiths 1999; Martins 1994; Peters \& Ord 2003; Stamps 1983).

Study design \& sampling strategy

We collected DNA samples from 177 A. norrisi and 377 C. atlas individuals from 38 sites within the four reserves $($ A. norrisi $=26$ sites, $C$. atlas $=31$ sites) (Fig. 1). We sampled over six consecutive sampling seasons (the spring/summer period when mallee lizards are most active), from Dec 2004 Feb 2005 (season 1) to Nov 2009 - Feb 2010 (season 6) (Table S1 in Supporting information). At each site, samples were collected over one to four sampling seasons (Table S1). Sample sizes varied from one to 34 individuals per site (Fig. 1, Table S1), so many of our analyses focussed on individuals as the sampling units (e.g. Pritchard et al. 2000; Rousset 2000), avoiding the need for large sample sizes and for pre-defined population boundaries. Analyses focussing on the population level were restricted to subsets of the data (Table 1).

Sites were sampled from four days to 49 years after fire (Fig. 1, Table S1) and were separated by average distances (range) of $4.7(0.3-15.2) \mathrm{km}$ at Hincks, 4.7 (0.6-11.6) km at Pinkawillinie, 1.4 (0.5-

This article is protected by copyright. All rights reserved. 
1.8) $\mathrm{km}$ at Munyaroo and $3.5(0.5-6.6) \mathrm{km}$ at Heggaton (Fig. 1). These distances are at a similar spatial scale to natural and prescribed fires in mallee (Bradstock \& Cohn 2002) and to commonly reported extents of genetic structure in lizards (e.g. Berry et al. 2005; Schrey et al. 2011b; Smith et al. 2009). At Hincks, with the most complex fire history, our sample sites also spanned a range of fire frequencies (0-5 fires since 1953, Fig. S1). At five of six sample sites burned during our study, we sampled both before and after the fires (Fig. 1, Table S1). Two sites at Pinkawillinie (P3 and P4, Dec 2005) and one site at Hincks (14, Dec 2006) were burnt by unplanned summer wildfires. One site at Hincks (I3, April 2006) and two sites at Heggaton (N4 and S4, April 2006) were burnt during prescribed fires conducted for a related study (Driscoll et al. 2012). The unplanned and prescribed fires were all of high severity, consuming all above ground vegetation.

Lizards were captured in pitfall traps as previously described (Smith et al. 2013) or hand-captured at three sites (Table S1). We used toe-clips to identify individuals upon recapture (Smith et al. 2013) and recorded the age (adult or juvenile) and sex of lizards collected at 'grid' sites at Hincks and Pinkawillinie (Table S1). Genetic analyses included all sampled individuals except where indicated. Blood and tissue from clipped toes were stored, respectively, on FTA paper (Whatman) and in liquid nitrogen or $5 \mathrm{ml}$ ethanol/physiological saline (1:1). Lizards were processed at a field base and released the following day at the capture location.

\section{Microsatellite DNA data}

We extracted DNA from FTA paper (Smith \& Burgoyne 2004) or from tissue samples using a modified Gentra kit (Qiagen). We amplified DNA at the polymorphic microsatellite DNA loci described by Smith et al. (2011), and used a subset of those loci that showed spatially consistent patterns of Hardy-Weinberg equilibrium and inconsequential levels of linkage disequilibrium (13 loci for $A$. norrisi: AmNo04, AmNo05, AmNo11, AmNo12, AmNo18, AmNo20, AmNo25, AmNo26, AmNo29,

This article is protected by copyright. All rights reserved. 
AmNo30, AmNo36, AmNo37, AmNo39; nine loci for C. atlas: CtAt02, CtAt03, CtAt08, CtAt09, CtAt12, CtAt15, CtAt18, CtAt24, CtAt30). Samples were genotyped on an ABI 3730 instrument (Applied Biosystems) with the size standard GS500 (-250) LIZ and alleles were scored with GeneMapper 4.0 (Applied Biosystems).

Question 1. Spatial drivers of gene flow and genetic diversity

The spatial effects of fire on gene flow and genetic diversity were investigated using all of the samples and analyses of genetic diversity, genetic structure and landscape resistance (Table 1).

Genetic diversity. To determine if post-fire succession affected genetic diversity, we analysed variation in two different diversity measures: site-level allelic richness standardised for sample size (N) and individual heterozygosity. Sample sizes varied across sites so we standardised allelic richness to $\mathrm{N}=5$ to encompass the full site variation in TSF. We conducted sensitivity analyses to test whether sample size influenced effects of TSF on allelic richness. To do this, we calculated allelic richness for $\mathrm{N}=6$ to 10 . As $\mathrm{N}$ increased, the number of sites included in the analysis decreased, so we lost power to test effects of TSF but were able to examine if the general pattern was consistent.

We used standArich (Alberto 2006) in R 3.0 (R Core Team 2013) to calculate allelic richness for each N. First, we performed multiple random reduction (Leberg 2002) for all sample sites with $\geq 5$ individuals. This produced a table of randomly subsampled individuals ranging from one to the number of individuals at the sample site (Alberto 2006). We conducted 100 random subsamples for each sample size at each site (Leberg 2002). Second, we calculated allelic richness standardised for each sample size of interest ( $N=5$ to $N=10)$. We used linear mixed-effects models in the Ime4 library (Bates et al. 2013) for R to examine the effect of TSF on allelic richness for each N. Because we sampled multiple sites within a single fire boundary, we fitted fire (a factor naming individual fire

This article is protected by copyright. All rights reserved. 
events) as a random effect and TSF and reserve as fixed effects. We examined interactions between TSF and reserve for $C$. atlas, but not $A$. norrisi which had a smaller range of TSF values within reserves. To estimate the effect of TSF on individual genetic diversity we first calculated the proportion of typed loci that were heterozygous in each individual. We modelled heterozygosity with the same formulation as for allelic richness (including interactive effects of TSF and reserve for both species), but also included site as an additional random term to account for potential dependence among individuals at the same site.

For both the allelic richness and heterozygosity analyses, we calculated $P$-values using Wald tests (Welsh 1996). We removed interactive terms and subsequently the reserve term if they were not significant $(P>0.05)$. Parameter estimates and standard errors were obtained using the AICcmodavg package (Mazerolle 2012).

Genetic structure. Spatial patterns of genetic structure corresponding to fire mosaics could indicate that gene flow was influenced by fire history. We examined population genetic structure in each species within each reserve separately and over the entire study region to infer broader patterns of gene flow. For each data set we used two different Bayesian clustering models. One was a nonspatial model implemented in STRUCTURE 2.3.2, which uses a Markov-chain Monte Carlo (MCMC) method to first identify the number of clusters $(K)$ in a sample at Hardy-Weinberg equilibrium and then assign each individual probabilistically to a cluster (Pritchard et al. 2000). The second was a spatial MCMC model implemented in GENELAND 3.3.0, similar to STRUCTURE but including geographic coordinates for each individual (Guillot et al. 2005). GENELAND is more sensitive to weak genetic structure because spatially adjacent individuals are more likely to be in the same cluster (Guillot et al. 2005).

This article is protected by copyright. All rights reserved. 
We ran STRUCTURE using the admixture and correlated allele frequency models for 500,000 MCMC repetitions after a burn-in of 200,000 , with five independent runs of each $K$ from 1 to 8 . We inferred the number of clusters in each data set by selecting the $K$ with the highest mean estimated model log-likelihood across the independent runs (Pritchard et al. 2000). We ran GENELAND for 500,000 MCMC repetitions, allowing $K$ to vary between 1 and 10 . We used the Dirichlet allele frequency model because the correlated allele frequency model can overestimate $K$ (Guillot et al. 2005) and we found it was unstable in preliminary analyses. We set spatial uncertainty of geographic coordinates to a conservatively high estimate of $1000 \mathrm{~m}$ to allow for large home-range movements (Read 1998; South 2010). We discarded the first 125,000 repetitions and then inferred $K$ from the mode of the posterior distribution. Five independent runs were conducted to check for consistency of results.

Landscape resistance. We developed five independent landscape resistance models based on features that might influence gene flow in the two lizard species: isolation by distance, sand dune topography, population density, time since fire and fire frequency (Table 2). The landscape features we examined related to previously derived measures of habitat suitability (see Table 2 ) which could affect gene flow through effects on either dispersal or population density. Our overall analysis approach was to (1) calculate genetic distance between all pairs of conspecific individuals within reserves as a measure of gene flow, (2) generate values of landscape resistance between pairs for each resistance model and (3) use simple (Mantel 1967) and partial (Smouse et al. 1986) Mantel tests in a causal modelling framework (Cushman \& Landguth 2010; Cushman et al. 2006; Legendre 1993) to determine the effects of each resistance model on gene flow separately.

Using SPAGEDI 1.2 (Hardy \& Vekemans 2002) we calculated genetic distance between each pair of conspecific individuals as $a_{r}$, an individual analogue to $F_{\mathrm{ST}} /\left(1-F_{\mathrm{ST}}\right)$ (Rousset 2000). We generated values of landscape resistance between each pair using a method based on circuit theory which takes into account all possible pathways between pairs (rather than the single, least-cost pathway

This article is protected by copyright. All rights reserved. 
used in many studies) (McRae \& Beier 2007). We compiled each resistance model on a separate raster grid with a $20 \mathrm{~m}$ resolution in ArcMap 10 (ESRI) and then calculated resistance between each pair for each model using CIRCUITSCAPE 3.5.4 (McRae \& Beier 2007). We defined the extent of our study landscapes with a $500 \mathrm{~m}$ buffer around the samples to encompass movement distances for both species (South 2010). We repeated the analysis using a $5 \mathrm{~km}$ buffer to encompass potential longer dispersals (Hoehn et al. 2007; Templeton et al. 2011) but found no meaningful effects of changing the buffer distance so only report results from the $500 \mathrm{~m}$ buffer analysis. The fire frequency resistance model was analysed only for Hincks with its more complex fire history (Fig. S1). At Heggaton, we conducted separate resistance analyses for samples collected before and after the 2006 prescribed fires (see Question 2). For the other three reserves, we included only samples collected after the most recent fire.

Analyses were conducted using the mantel function in the ecodist library (Goslee \& Urban 2007) for R 3.0 (R Core Team 2013). P-values were obtained with 5000 joint randomisations of rows and columns of one matrix (Goslee \& Urban 2007). For isolation by distance models, we used simple Mantel tests and one-tailed $P$ values to determine significant $(\alpha=0.05)$ relationships between genetic and geographic distance within reserves (Goslee \& Urban 2007). For other resistance models we used partial Mantel tests and two-tailed $P$ values to determine significant relationships between genetic distance and landscape resistance, given the spatial distance between samples (Goslee \& Urban 2007). When there was a significant correlation in the first partial Mantel test, we calculated the effect of the isolation by distance model on genetic distance while controlling for the landscape resistance model. Where the first partial Mantel test was significant and the second test was nonsignificant we inferred significant effects of that landscape resistance model on genetic distance (Cushman et al. 2006; Legendre 1993).

This article is protected by copyright. All rights reserved. 
The sand dune topography model was based on elevation data sourced from the Shuttle Radar Topographic Mission one-second bare earth version of Australia (CSIRO 2011). Elevations were projected as points and interpolated with ANUDEM (Hutchinson 2011) to create digital elevation models that distinguished dunes from swales (Fig. S2). The three fire-related resistance models (TSF, fire frequency and population density) were derived from two different spatial data sets, one containing the year of the most recent fire, the other containing the number of fires since 1953 (South Australian Department for Environment, Water and Natural Resources). For the population density model we used the mean number of captures predicted from TSF (Smith et al. 2013) enabling us to parameterise areas we had not sampled. Estimates were available for Hincks and Pinkawillinie only, so we generated predictions for Munyaroo and Heggaton using published data (Table S2, Fig. S3). We examined the population density model of gene flow only for locations where there was a significant response to TSF (A. norrisi at Heggaton, C. atlas at Hincks and Pinkawillinie). The TSF and population density landscape models were both based on the same spatial data set derived from the most recent fire in each reserve. The difference between the models was that the TSF model examined linear effects of the number of years since fire, while the population density model allowed non-linear responses, reflecting population responses in each species (Smith et al. 2013).

Question 2. Immediate, temporal drivers of post-fire genetic structure

The immediate impacts of fire were investigated by comparing genetic structure before and after fire across the whole landscape at Heggaton, where we had similar numbers of pre- and post-fire samples (Fig. 1). For each species, we applied the landscape resistance analysis method described for Question 1 to the pre- and post-fire samples separately.

This article is protected by copyright. All rights reserved. 
Question 3. Modes of post-fire re-establishment

Sources of re-establishment were investigated using samples from five of the six sites that burned during the study (Fig. 1, Table S1). We examined results from the STRUCTURE and GENELAND analyses of the whole sample within reserves, described for Question 1. If genetic structure was detectable, genetic differentiation between pre- and post-fire samples may indicate a stronger role of immigration than re-establishment from local survivors of the fire. We also applied STRUCTURE analyses separately to $C$. atlas samples from each site that burned during the study (sample sizes for A. norrisi were too small $(\leq 7$, Table $\mathrm{S} 1))$ to compare the sensitivity to detect genetic structure between pre- and post-fire samples.

Question 4. Demographic drivers of genetic diversity

At 'grid' sites at Hincks and Pinkawillinie (Table S1) where age and sex were recorded, we summarised proportions of adults and juveniles and proportions of adult males and adult females for each species. We used binomial generalised linear mixed models in Ime4 to analyse whether the age and sex ratios were affected by TSF, reserve (for $C$. atlas only) and sampling season for each species separately. Site was fitted as a random effect. To investigate sex-biased dispersal in each species, we used simple Mantel tests of isolation by distance on data from adult males and adult females separately.

To determine if fire-related genetic patterns could be explained by demographic changes in $A$. norrisi, we simulated genetic data for two demographic scenarios using EASYPOP 2.0.1 (Balloux 2001). Ctenotus atlas did not have any detectable genetic structure within reserves so we did not simulate its population structure. For each scenario, we used a two-dimensional spatial model of 10 $x 10$ cells and generated data for 10 populations, each with 30 males and 30 females. We simulated

This article is protected by copyright. All rights reserved. 
data for 13 independent loci, each with 18 possible allelic states (Smith et al. 2011). We used a twophase mutation model, weighted with $5 \%$ infinite alleles model and $95 \%$ step-wise mutation model (Di Rienzo et al. 1994) and a mutation rate of 0.0001. Alleles were randomly assigned in the initial population.

First, we simulated populations with isolation by distance in males but not females to mimic the observed patterns in our empirical data. These were used to represent populations in unburnt habitat with stable social structures and mating systems. We specified a polygynous mating system (typical for agamids (Stamps 1983)) with 50\% matings by subordinate males. We set the proportion of migration to 0.5 for males and 1 for females, and the mean dispersal distance to 4 for males and 12 for females. We ran the stable scenario for 20 generations, based on a generation time of $2 \mathrm{yr}$ (South 2010) and 40 years since fire - relatively long unburnt habitat in our study system.

Second, we simulated populations with disrupted mating systems and increased male dispersal - a scenario which may occur immediately after fire (Banks et al. 2012). We specified a random mating system and set the proportion of migration to 1 and the mean dispersal distance to 12 for both sexes. We ran the disturbed scenario for two generations to represent populations in the first four years after fire.

We simulated 20 replicates of each scenario to determine consistency in results, calculated mean allelic richness, and used simple Mantel tests to test for isolation by distance among simulated populations.

This article is protected by copyright. All rights reserved. 


\section{Results}

Question 1. Spatial drivers of gene flow and genetic diversity

Genetic diversity. Each species showed significant main effects of TSF on allelic richness, standardised to a sample size of five individuals. Allelic richness increased with TSF in $C$. atlas $(P=$ 0.037, Fig. 2a) and decreased with TSF in $A$. norrisi $(P=0.003$, Fig. 2b). In $A$. norrisi, but not $C$. atlas, there were also main effects of reserve, with Munyaroo having significantly lower allelic richness than Hincks and Pinkawillinie $(P<0.001$, Fig. 2 c). Sensitivity analyses showed consistent significant effects of TSF on allelic richness across all sample size standardisations except $N=7(P=0.09)$ and 10 $(P=0.07)$ for $C$. atlas (Table S3, Fig. S4, Fig. S5). The reserve effect on allelic richness in A. norrisi disappeared when $\mathrm{N}>6$ because it was driven by the site at Munyaroo which had only six individuals. There were no effects of TSF or reserve on individual heterozygosity in either species.

Genetic structure. Both within each reserve and across the whole study region, STRUCTURE indicated that all conspecific individuals belonged to a single genetic cluster (Fig. S6). However, GENELAND suggested that $C$. atlas individuals at Hincks were genetically different from those at the other reserves (Fig. 3a, Fig. S7), although assignment probabilities were always $<71 \%$ suggesting only weak differentiation (Fig. 3a). One 'ghost' cluster (Guillot et al. 2005) to which no individuals were assigned was also identified (the dark band at the bottom of Fig. 3a). For A. norrisi, GENELAND results indicated that individuals at N3 and N4 (last burnt in 1960) were genetically differentiated from the other six sites at Heggaton (Fig. 3b, Fig. S7) but there was no differentiation across the fire mosaic at the southern Heggaton sites (Fig. 3b). There was no convincing evidence of genetic structure in any other data set from individual reserves or across the study region (Fig. S6, Fig. S7, Fig. S8). Thus, there was no evidence that patterns of genetic structure were related to fire regimes.

This article is protected by copyright. All rights reserved. 
Landscape resistance. There were no significant effects of landscape resistance on genetic distance in C. atlas (Table S4). For A. norrisi, we found significant isolation by distance at Hincks $\left(r_{\mathrm{M}}=0.128, P\right.$ $<0.001)$ and at Heggaton, both before $\left(r_{\mathrm{M}}=0.153, P=0.034\right)$ and after $\left(r_{\mathrm{M}}=0.162, P=0.045\right)$ the 2006 fires, while at Munyaroo, there was a significant effect of the TSF model on genetic distance $\left(r_{\mathrm{M}}\right.$ $=0.555, P=0.045)$. There, individuals in long-unburnt habitats were more genetically different from each other than individuals in recently burnt habitat.

Question 2. Immediate, temporal drivers of post-fire genetic structure

There were no changes between the pre- and post-fire samples from Heggaton that would indicate an immediate, temporal effect of fire on landscape genetic structure (Table S4).

Question 3. Modes of post-fire re-establishment

At the sites that burned during the study, samples collected before or after fire were genetically indistinguishable, whether analysed alone or with other samples from the same reserve. Although we observed genetic differentiation at Heggaton using GENELAND (Fig. 3b), this was related to the spatial location of samples, rather than whether they were collected before or after fires.

Question 4. Demographic drivers of genetic diversity

We observed a female biased sex ratio in both species at Hincks (Table S5) but could not differentiate between a demographic effect or an effect of sex differences in capture rates. There were no significant effects of TSF, location or sampling season on age structure or sex ratio in either species.

This article is protected by copyright. All rights reserved. 
For $A$. norrisi at Hincks we found significant isolation by distance in adult males $\left(r_{\mathrm{M}}=0.180, P=\right.$ 0.022) but not adult females (Table S4), indicating female-biased dispersal. The significant isolation by distance in the overall sample for $A$. norrisi (adults and juveniles) was unlikely to have been driven solely by relatedness among pre-dispersed juveniles because the same effect was observed in adult males. There was no evidence for sex-biased dispersal in C. atlas (Table S4).

Our first simulation consistently produced significant isolation by distance in males but not females (Table S6), reflecting the pattern in our empirical data. The second simulation, with a disruption of the polygynous mating system and increased male dispersal, resulted in no isolation by distance for either sex (Table S6) and an increase in mean allelic richness (first simulation $=11.8$, second simulation $=17.3 ; \mathrm{t}=-80.13, P<0.001)$.

\section{Discussion}

We discovered contrasting effects of fire on genetic diversity in two lizard species. Allelic richness decreased with TSF in A. norrisi and increased in C. atlas (Question 1). There were no consistent effects of fire-related habitat features or topography on gene flow in either species (Question 1) but we found isolation by distance in A. norrisi. We found no evidence of an immediate, temporal effect of fire on gene flow in either species (Question 2) and we were unable to distinguish between survival and immigration as modes of post-fire re-establishment (Question 3). Post-fire habitat succession did not appear to affect movement or dispersal in our study species as it has in other animal species (Murphy et al. 2010; Templeton et al. 2011). In the absence of habitat resistance to gene flow, the observed effects of TSF on genetic diversity might be related to post-fire changes in social structure and mating systems (Pilot et al. 2010; Ross 2001) or population size (Frankham 1996) (Question 4). Alternatively, we might have had insufficient resolution in our genetic markers to

This article is protected by copyright. All rights reserved. 
detect effects of fire on gene flow. We discuss these biological hypotheses and statistical caveats below.

Female-biased dispersal in A. norrisi likely reflects the territorial social structure and polygynous mating system common in agamids (Griffiths 1999; Martins 1994; Stamps 1983) and documented in the closely related A. muricatus (Peters \& Ord 2003). Our simulations showed that short-term disruptions of this social structure can increase genetic diversity, explaining the higher allelic richness in A. norrisi from recently burned habitat. Disrupted social structure has caused elevated genetic diversity through increased outbreeding in lemon sharks (Negaprion brevirostris) following habitat loss (DiBattista et al. 2011) and in mountain brushtail possums (Trichosurus cunninghami) following fire (Banks et al. 2012). In A. norrisi, the decline in allelic richness with TSF might reflect a stabilisation of the social structure, through establishment of territories and increased relatedness among proximate individuals (e.g. Gardner et al. 2001). At Munyaroo, genetic distance between individuals was lower in more recently burnt habitat, supporting a hypothesis of strong social structure in long-unburnt habitat. However, we did not observe this at the other reserves so continued research of lizard movement and behaviour across fire mosaics is needed to provide further support to our hypothesis.

For C. atlas, increased genetic diversity with TSF might result from changing population density. Genetic diversity is positively related to population size (Frankham 1996) and fire decreases population density in C. atlas (Smith et al. 2013). However, we did not find variation in gene flow that has accompanied habitat-related changes in genetic diversity in other lizards (Berry et al. 2005; Hoehn et al. 2007; Levy et al. 2010). In another late-successional skink species, Plestiodon reynoldsi, Schrey et al. (2011b) reported that genetic diversity increased with TSF, reflecting changes in population density and gene flow. Increases in population size without immigration would lead to decreases in genetic diversity through genetic drift over successive generations (Lacy 1987).

This article is protected by copyright. All rights reserved. 
Ctenotus atlas must therefore maintain gene flow as population size increases but we could not detect increased gene flow that would reduce loss of genetic diversity through genetic drift.

Maintenance of gene flow through dispersal in fire-prone ecosystems may be an adaptation to temporally dynamic habitats (Brown et al. 2013; Pereoglou et al. 2013; Pierson et al. 2010). Fire mosaics did not appear to form dispersal barriers in either of our study species, supporting this suggestion. This assumes we collected enough samples from across the landscape to detect barriers (Berry et al. 2004) and that the time between disturbance and sample collection was long enough for barriers to form (Landguth et al. 2010). Our study landscapes were characterised by complex fire mosaics. A more pronounced effect of fire on genetic structure might occur in more heterogeneous habitats, where entire habitat patches are burned and population bottlenecks occur (Banks et al. 2013).

Despite disagreement over the reliability of the causal modelling approach that we followed (Cushman et al. 2013; Graves et al. 2013; Guillot \& Rousset 2013; Legendre \& Fortin 2010), there are few available alternatives that circumvent the problems identified. Cushman \& Landguth (2010) suggested that causal modelling can reliably identify a correct model of landscape resistance among competing hypotheses. Others have claimed poor performance of this approach because it assumes linearity between distance matrices (Legendre \& Fortin 2010) and disregards information about a range of factors (mating, dispersal, inheritance) influencing gene flow (Graves et al. 2013). These issues may have limited our ability to detect effects of landscape resistance on gene flow. However, the weak genetic structure revealed by non-distance-based analyses (STRUCTURE) suggest that landscape resistance patterns would be difficult to detect in our study system. Cushman et al. (2013) found partial Mantel tests had inflated Type I error rates but low Type II error rates. This bias would have limited impact on our conclusions because most of our partial Mantel tests were insignificant.

This article is protected by copyright. All rights reserved. 
Guillot \& Rousset (2013) showed that simple Mantel tests are appropriate for analysing isolation by distance so our conclusions regarding isolation by distance in $A$. norrisi are unlikely to be biased.

Detecting temporal genetic changes to infer that fire disrupted gene flow or that re-establishment occurred through immigration might require stronger genetic structure than we found in our target species (Berry et al. 2004). We recommend long-term DNA sample collection in fire-prone ecosystems to develop better understanding of the effect of fire on genetic structure of natural populations. Further studies should focus on those species with limited dispersal relative to the spatial scale of fire mosaics which are likely to most be affected by fire management decisions.

By comparing two ecologically different lizard species we discovered species-specific genetic responses to post-fire habitat succession. We propose that differences in the relationship between genetic diversity and TSF resulted from differences in the influence of population density and social structure. We predict stronger effects of disturbance on genetic diversity for species with stable social organisation. Our study has shown how genetic investigations can uncover part of the mechanism that causes species to vary in their distribution and abundance under different fire regimes (Banks et al. 2013; Keith 2012). Combining this approach with direct ecological studies of movement and behaviour will help ensure that fire management is conducted at spatial and temporal scales appropriate for biodiversity conservation.

\section{Acknowledgements}

Over 100 volunteers were involved in field work, particularly Samantha Blight, Simone Dalgairns, Juliana Lazzari, Kevin Mayes, Andrew Murphy, Sally South and Catherine Whitehead. Joe Tilley and members of the South Australian Department of Environment, Water and Natural Resources (DEWNR) at Pt Lincoln provided field support. Kathy Saint, Terry Bertozzi and Steve Donnellan

This article is protected by copyright. All rights reserved. 
helped with molecular data collection, John Stein helped compile spatial data and Sam Banks gave analytical advice. Ross Bradstock, David Keith, Sonia Kleindorfer and Andrew Lowe and gave advice during project development. Michael Clarke, Sam Cushman, Aaron Schrey, Paul Sunnucks, the Subject Editor Stephen Spear and five anonymous reviewers provided constructive criticism on the manuscript. This research was supported by funds from The Australian Research Council, The Native Vegetation Council of South Australia, DEWNR, The Wildlife Conservation Fund, The Sir Mark Mitchell Research Foundation, The Lirabenda Endowment Fund, The Ecological Society of Australia and The Australian National University. We worked under scientific permit S25589 (DEWNR) and animal ethics permit E256 (Flinders University).

\section{References}

Alberto $F(2006)$ standArich: an R package to estimate population allelic richness using standardized sample size. CCMAR, University of the Algarve, Portugal.

http://www.ccmar.ualg.pt/maree/software.php?soft=sarich

Balloux F (2001) EASYPOP (Version 1.7): a computer program for population genetics simulations. Journal of Heredity, 92, 301-302.

Banks SC, Blyton MDJ, Blair D, McBurney L, Lindenmayer DB (2012) Adaptive responses and disruptive effects: how major wildfire influences kinship-based social interactions in a forest marsupial. Molecular Ecology, 21, 673-684.

Banks SC, Cary GJ, Smith AL, Davies I, Driscoll DA, Gill AM, Lindenmayer DB, Peakall R (2013) How does ecological disturbance influence genetic diversity? Trends in Ecology and Evolution, 28, 670679.

This article is protected by copyright. All rights reserved. 
Banks SC, Dujardin M, McBurney L, Blair D, Barker M, Lindenmayer DB (2011) Starting points for small mammal population recovery after wildfire: recolonisation or residual populations? Oikos, 120, 26-37.

Bates D, Maechler M, Bolker B (2013) Ime4: linear mixed-effects models using S4 classes. R package, version 0.999999-2. http://Ime4.r-forge.r-project.org/ (accessed October 2013).

Berry O, Tocher MD, Gleeson DM, Sarre SD (2005) Effect of vegetation matrix on animal dispersal: genetic evidence from a study of endangered skinks. Conservation Biology, 19, 855-864.

Berry O, Tocher MD, Sarre SD (2004) Can assignment tests measure dispersal? Molecular Ecology, $13,551-561$.

Bradstock RA, Cohn JS (2002) Fire regimes and biodiversity in semi-arid mallee ecosystems. In Flammable Australia: the fire regimes and biodiversity of a continent. eds Bradstock RA, Williams JE, Gill AM. Cambridge University Press, Cambridge.

Brown SM, Harrisson KA, Clarke RH, Bennett AF, Sunnucks P (2013) Limited population structure, genetic drift and bottlenecks characterise an endangered bird species in a dynamic, fire-prone ecosystem. PLOS One, 8, e59732.

Butz RJ (2009) Traditional fire management: historical fire regimes and land use change in pastoral East Africa. International Journal of Wildland Fire, 18, 442-450.

Clarke MF (2008) Catering for the needs of fauna in fire management: science or just wishful thinking? Wildlife Research, 35, 385-394.

CSIRO (2011) One-second SRTM digital elevation model. Commonwealth Scientific and Industrial Research Organisation. http://www.csiro.au/science/One-second-SRTM-Digital-ElevationModel.html

This article is protected by copyright. All rights reserved. 
Cushman S, Wasserman T, Landguth E, Shirk A (2013) Re-evaluating causal modeling with Mantel tests in landscape genetics. Diversity, 5, 51-72.

Cushman SA, Landguth EL (2010) Spurious correlations and inference in landscape genetics. Molecular Ecology, 19, 3592-3602.

Cushman SA, McKelvey KS, Hayden J, Schwartz MK (2006) Gene flow in complex landscapes: testing multiple hypotheses with causal modeling. The American Naturalist, 168, 486-499.

Di Rienzo A, Peterson AC, Garza JC, Valdes AM, Slatkin M, Freimer NB (1994) Mutational processes of simple-sequence repeat loci in human populations. Proceedings of the National Academy of Sciences USA, 91, 3166-3170.

DiBattista JD, Feldheim KA, Garant D, Gruber SH, Hendry AP (2011) Anthropogenic disturbance and evolutionary parameters: a lemon shark population experiencing habitat loss. Evolutionary Applications, 4, 1-17.

Driscoll DA, Hardy CM (2005) Dispersal and phylogeography of the agamid lizard Amphibolurus nobbi in fragmented and continuous habitat. Molecular Ecology, 14, 1613-1629.

Driscoll DA, Henderson MK (2008) How many common reptile species are fire specialists? A replicated natural experiment highlights the predictive weakness of a fire succession model. Biological Conservation, 141, 460-471.

Driscoll DA, Lindenmayer DB, Bennett AF, Bode M, Bradstock RA, Cary GJ, Clarke MF, Dexter N, Fensham R, Friend G, Gill AM, James S, Kay G, Keith DA, MacGregor C, Russell-Smith J, Salt D, Watson JEM, Williams RJ, York A (2010) Fire management for biodiversity conservation: key research questions and our capacity to answer them. Biological Conservation, 143, 1928-1939.

This article is protected by copyright. All rights reserved. 
Driscoll DA, Smith AL, Blight SR, Maindonald J (2012) Reptile responses to fire and the risk of postdisturbance sampling bias. Biodiversity and Conservation, 21, 1607-1625.

Frankham R (1996) Relationship of genetic variation to population size in wildlife. Conservation Biology, 10, 1500-1508.

Frankham R (1997) Do island populations have less genetic variation than mainland populations? Heredity, 78, 311-327.

Gardner MG, Bull CM, Cooper SJB, Duffield GA (2001) Genetic evidence for a family structure in stable social aggregations of the Australian lizard Egernia stokesii. Molecular Ecology, 10, 175-183.

Goslee SC, Urban DL (2007) The ecodist package for dissimilarity-based analysis of ecological data. Journal of Statistical Software, 22, 1-19.

Graves TA, Beier P, Royle JA (2013) Current approaches using genetic distances produce poor estimates of landscape resistance to interindividual dispersal. Molecular Ecology, 22, 3888-3903.

Griffiths AD (1999) Demography and home range of the frillneck lizard, Chlamydosaurus kingii (Agamidae), in northern Australia. Copeia, 1999, 1089-1096.

Guillot G, Estoup A, Mortier F, Cosson J-F (2005) A spatial statistical model for landscape genetics. Genetics, 170, 1261-1280.

Guillot G, Rousset F (2013) Dismantling the Mantel tests. Methods in Ecology and Evolution, 4, 336344.

Hardy OJ, Vekemans X (2002) SPAGEDI: a versatile computer program to analyse spatial genetic structure at the individual or population levels. Molecular Ecology Notes, 2, 618-620.

Haslem A, Kelly LT, Nimmo DG, Watson SJ, Kenny SA, Taylor RS, Avitabile SC, Callister KE, SpenceBailey LM, Clarke MF, Bennett AF (2011) Habitat or fuel? Implications of long-term, post-fire This article is protected by copyright. All rights reserved. 
dynamics for the development of key resources for fauna and fire. Journal of Applied Ecology, 48, 247-256.

Heffernan LD (2008) Microhabitat selection by lizards in southern Australia's semi-arid MurrayMallee region. Unpublished Honours Thesis, La Trobe University, Bundoora.

Hoehn M, Sarre S, Henle K (2007) The tales of two geckos: does dispersal prevent extinction in recently fragmented populations? Molecular Ecology, 16, 3299-3312.

Holland GJ, Bennett AF (2011) Recolonization of forest fragments by a native rodent following experimental 'extinctions'. Austral Ecology, 36, 521-529.

Hutchinson MF (2011) ANUDEM version 5.3, user guide. Fenner School of Environment and Society, Australian National University, Canberra.

Keith DA (2012) Functional traits: their roles in understanding and predicting biotic responses to fire regimes from individuals to landscapes. In Flammable Australia: fire regimes, biodiversity and ecosystems in a changing world. eds Bradstock RA, Gill AM, Williams RJ, pp. 97-125. CSIRO Publishing, Collingwood, Victoria.

Kelly LT, Nimmo DG, Spence-Bailey LM, Taylor RS, Watson SJ, Clarke MF, Bennett AF (2012) Managing fire mosaics for small mammal conservation: a landscape perspective. Journal of Applied Ecology, 49, 412-421.

Konvicka M, Zimmermann K, Klimova M, Hula V, Fric Z (2012) Inverse link between density and dispersal distance in butterflies: field evidence from six co-occurring species. Population Ecology, 54, 91-101.

Lacy RC (1987) Loss of genetic diversity from managed populations: interacting effects of drift, mutation, immigration, selection, and population subdivision. Conservation Biology, 1, 143-158.

This article is protected by copyright. All rights reserved. 
Landguth EL, Cushman SA, Schwartz MK, McKelvey KS, Murphy M, Luikart G (2010) Quantifying the lag time to detect barriers in landscape genetics. Molecular Ecology, 19, 4179-4191.

Leberg PL (2002) Estimating allelic richness: effects of sample size and bottlenecks. Molecular Ecology, 11, 2445-2449.

Legendre P (1993) Spatial autocorrelation: trouble or new paradigm? Ecology, 74, 1659-1673.

Legendre P, Fortin M-J (2010) Comparison of the Mantel test and alternative approaches for detecting complex multivariate relationships in the spatial analysis of genetic data. Molecular Ecology Resources, 10, 831-844.

Levy E, Kennington WJ, Tomkins JL, LeBas NR (2010) Land clearing reduces gene flow in the granite outcrop-dwelling lizard, Ctenophorus ornatus. Molecular Ecology, 19, 4192-4203.

Lindenmayer DB, Wood JT, MacGregor C, Michael DR, Cunningham RB, Crane M, Montague-Drake R, Brown D, Muntz R, Driscoll DA (2008) How predictable are reptile responses to wildfire? Oikos, 117, 1086-1097.

Lyet A, Cheylan M, Prodon R, Besnard A (2009) Prescribed fire and conservation of a threatened mountain grassland specialist: a capture-recapture study on the Orsini's viper in the French alps. Animal Conservation, 12, 238-248.

Mantel N (1967) The detection of disease clustering and a generalized regression approach. Cancer Research, 27, 209-220.

Martins EP (1994) Phylogenetic perspectives on the evolution of lizard territoriality. In Lizard Ecology: Historical and Experimental Perspectives. eds Vitt LJ, Pianka ER, pp. 117-144. Princeton University Press, Princeton, N.J.

This article is protected by copyright. All rights reserved. 
Mazerolle MJ (2012) AICcmodavg. R package, version 1.26. http://cran.r-

project.org/web/packages/AICcmodavg/index.html (accessed January 2013).

McRae BH, Beier P (2007) Circuit theory predicts gene flow in plant and animal populations.

Proceedings of the National Academy of Sciences USA, 104, 19885-19890.

Murphy MA, Evans JS, Storfer A (2010) Quantifying Bufo boreas connectivity in Yellowstone National Park with landscape genetics. Ecology, 91, 252-261.

Neuwald JL, Templeton AR (2013) Genetic restoration in the eastern collared lizard under prescribed woodland burning. Molecular Ecology, 22, 3666-3679.

Nimmo DG, Kelly LT, Spence-Bailey LM, Watson SJ, Haslem A, White JG, Clarke MF, Bennett AF (2012) Predicting the century-long post-fire responses of reptiles. Global Ecology and Biogeography, 21, 1062-1073.

Nimmo DG, Kelly LT, Spence-Bailey LM, Watson SJ, Taylor RS, Clarke MF, Bennett AF (2013) Fire mosaics and reptile conservation in a fire-prone region. Conservation Biology, 27, 345-353.

Parr CL, Andersen AN (2006) Patch mosaic burning for biodiversity conservation: a critique of the pyrodiversity paradigm. Conservation Biology, 20, 1610-1619.

Pausas JG, Lloret F (2007) Spatial and temporal patterns of plant functional types under simulated fire regimes. International Journal of Wildland Fire, 16, 484-492.

Peakall R, Lindenmayer DB (2006) Genetic insights into population recovery following experimental perturbation in a fragmented landscape. Biological Conservation, 132, 520-532.

Pereoglou F, Lindenmayer DB, MacGregor C, Ford F, Wood J, Banks SC (2013) Landscape genetics of an early successional specialist in a disturbance-prone environment. Molecular Ecology, 22, 12671281.

This article is protected by copyright. All rights reserved. 
Peters RA, Ord TJ (2003) Display response of the Jacky Dragon, Amphibolurus muricatus (Lacertilia: Agamidae), to intruders: a semi-Markovian process. Austral Ecology, 28, 499-506.

Pianka ER (1969) Sympatry of desert lizards (Ctenotus) in Western Australia. Ecology, 50, 1012-1030.

Pianka ER (1972) Zoogeography and speciation of Australian desert lizards: an ecological perspective. Copeia, 1972, 127-145.

Pierson JC, Allendorf FW, Drapeau P, Schwartz MK (2013) Breed locally, disperse globally: fine-scale genetic structure despite landscape-scale panmixia in a fire-specialist. PLOS One, 8, e67248.

Pierson JC, Allendorf FW, Saab V, Drapeau P, Schwartz MK (2010) Do male and female black-backed woodpeckers respond differently to gaps in habitat? Evolutionary Applications, 3, 263-278.

Pilot M, Dahlheim ME, Hoelzel AR (2010) Social cohesion among kin, gene flow without dispersal and the evolution of population genetic structure in the killer whale (Orcinus orca). Journal of Evolutionary Biology, 23, 20-31.

Porter AH (1999) Refugees from lost habitat and reorganization of genetic population structure. Conservation Biology, 13, 850-859.

Prevedello JA, Forero-Medina G, Vieira MV (2010) Movement behaviour within and beyond perceptual ranges in three small mammals: effects of matrix type and body mass. Journal of Animal Ecology, 79, 1315-1323.

Pritchard JK, Stephens M, Donnelly P (2000) Inference of population structure using multilocus genotype data. Genetics, 155, 945-959.

R Core Team (2013) R: a language and environment for statistical computing. http://www.Rproject.org, R Foundation for Statistical Computing, Vienna, Austria.

This article is protected by copyright. All rights reserved. 
Read JL (1998) The ecology of sympatric scincid lizards (Ctenotus) in arid South Australia. Australian Journal of Zoology, 46, 617-629.

Regan HM, Crookston JB, Swab R, Franklin J, Lawson DM (2010) Habitat fragmentation and altered fire regime create trade-offs for an obligate seeding shrub. Ecology, 91, 1114-1123.

Robinet C, Lance DR, Thorpe KW, Onufrieva KS, Tobin PC, Liebhold AM (2008) Dispersion in time and space affect mating success and Allee effects in invading gypsy moth populations. Journal of Animal Ecology, 77, 966-973.

Ross KG (2001) Molecular ecology of social behaviour: analyses of breeding systems and genetic structure. Molecular Ecology, 10, 265-284.

Rousset F (2000) Genetic differentiation between individuals. Journal of Evolutionary Biology, 13, 5862. Sanz-Aguilar A, Anadón JD, Giménez A, Ballestar R, Graciá E, Oro D (2011) Coexisting with fire: the case of the terrestrial tortoise Testudo graeca in mediterranean shrublands. Biological Conservation, $144,1040-1049$.

Schrey AW, Ashton KG, Heath S, McCoy ED, Mushinsky HR (2011a) Fire alters patterns of genetic diversity among 3 lizard species in Florida scrub habitat. Journal of Heredity, 102, 399-408.

Schrey AW, Fox AM, Mushinsky HR, McCoy ED (2011b) Fire increases variance in genetic characteristics of Florida Sand Skink (Plestiodon reynoldsi) local populations. Molecular Ecology, 20, 56-66.

Schtickzelle N, Joiris A, Van Dyck H, Baguette M (2007) Quantitative analysis of changes in movement behaviour within and outside habitat in a specialist butterfly. BMC Evolutionary Biology, $7,4$.

This article is protected by copyright. All rights reserved. 
Shanahan DF, Possingham HP, Riginos C (2011) Models based on individual level movement predict spatial patterns of genetic relatedness for two Australian forest birds. Landscape Ecology, 26, 137148.

Short Bull RA, Cushman SA, Mace R, Chilton T, Kendall KC, Landguth EL, Schwartz MK, McKelvey K, Allendorf FW, Luikart G (2011) Why replication is important in landscape genetics: American black bear in the Rocky Mountains. Molecular Ecology, 20, 1092-1107.

Smith AL, Bull CM, Driscoll DA (2012) Post-fire succession affects abundance and survival but not detectability in a knob-tailed gecko. Biological Conservation, 145, 139-147.

Smith AL, Bull CM, Driscoll DA (2013) Successional specialization in a reptile community cautions against widespread planned burning and complete fire suppression. Journal of Applied Ecology, 50, 1178-1186.

Smith AL, Gardner MG, Bull CM, Driscoll DA (2011) Primers for novel microsatellite markers in "firespecialist" lizards (Amphibolurus norrisi, Ctenotus atlas and Nephrurus stellatus) and their performance across multiple populations. Conservation Genetics Resources, 3, 345-350.

Smith AL, Gardner MG, Fenner AL, Bull CM (2009) Restricted gene flow in the endangered pygmy bluetongue lizard (Tiliqua adelaidensis) in a fragmented agricultural landscape. Wildlife Research, 36, 466-478.

Smith LM, Burgoyne LA (2004) Collecting, archiving and processing DNA from wildlife samples using FTA(R) databasing paper. BMC Ecology, 4, http://www.biomedcentral.com/1472-6785/1474/1474.

Smouse PE, Long JC, Sokal RR (1986) Multiple regression and correlation extensions of the Mantel test of matrix correspondence. Systematic Zoology, 35, 627-632.

This article is protected by copyright. All rights reserved. 
South SL (2010) Natural history and spatial ecology of Amphibolurus norrisi in southern Australia.

Unpublished honours thesis, Flinders University, Adelaide.

Spear SF, Storfer A (2010) Anthropogenic and natural disturbance lead to differing patterns of gene flow in the Rocky Mountain tailed frog, Ascaphus montanus. Biological Conservation, 143, 778-786.

Specht RL (1972) The Vegetation of South Australia. AB James, Government Printer, Adelaide, SA.

Stamps JA (1983) Sexual selection, sexual dimorphism and territoriality. In Lizard Ecology: Studies of a Model Organism eds Huey RB, Pianka ER, Schoener TW. Harvard University Press, Cambridge, USA.

Stephens PA, Sutherland WJ, Freckleton RP (1999) What is the Allee effect? Oikos, 87, 185-190.

Templeton AR, Brazeal H, Neuwald JL (2011) The transition from isolated patches to a metapopulation in the eastern collared lizard in response to prescribed fires. Ecology, 92, 17361747.

Twidale CR, Campbell EM (1985) The form of the land surface. In Natural history of Eyre Peninsula. eds Twidale CR, Tyler MJ, Davies M. Royal Society of South Australia, Adelaide, SA.

Welsh AH (1996) Aspects of Statistical Inference. John Wiley \& Sons, Inc., New York.

Westgate MJ, Driscoll DA, Lindenmayer DB (2012) Can the intermediate disturbance hypothesis and information on species traits predict anuran responses to fire? Oikos, 121, 1516-1524.

Wilson S, Swan G (2010) A Complete Guide to Reptiles of Australia, 3 edn. New Holland, Sydney.

Wright S (1943) Isolation by distance. Genetics, 28, 114-138.

This article is protected by copyright. All rights reserved. 


\section{Data accessibility}

Appendix S1 is a spreadsheet containing the sample information, location and genotype for each individual. Input files for analyses, pairwise landscape resistance values and simulation parameters are also included.

\section{Author contributions}

ALS, CMB, MGG and DAD designed the research and collected the data; ALS analysed the data and wrote the manuscript with extensive input from $C M B, M G G$ and $D A D$.

\section{Supporting information}

Additional supporting information may be found in the online version of this article:

Table S1 Sites where DNA samples from Amphibolurus norrisi and Ctenotus atlas were collected on the Eyre Peninsula, South Australia.

Fig. S1 A spatial mosaic of different fire frequencies at Hincks.

Fig. S2 A digital elevation model used to test the effect of sand dunes on gene flow in Amphibolurus norrisi and Ctenotus atlas.

Table S2 Results from generalised linear mixed models investigating the effect of time since fire on capture rates in Amphibolurus norrisi and Ctenotus atlas at Munyaroo and Heggaton.

Fig. S3 The effect of time since fire on capture rates in Amphibolurus norrisi and Ctenotus atlas at Munyaroo and Heggaton.

Table S3 Results from linear mixed models to examine the effect of time since fire and reserve on allelic richness in Amphibolurus norrisi and Ctenotus atlas.

Fig. S4 Results from a sensitivity analysis to test how changing the sample size standardisation influenced the effect of time since fire on allelic richness in Ctenotus atlas.

This article is protected by copyright. All rights reserved. 
Fig. S5 Results from a sensitivity analysis to test how changing the sample size standardisation influenced the effect of time since fire on allelic richness in Amphibolurus norrisi.

Fig. S6 Results from STRUCTURE indicating the most likely number of clusters in the samples from Amphibolurus norrisi and Ctenotus atlas.

Fig. S7 Results from GENELAND indicating the most likely number of clusters in the samples from Amphibolurus norrisi and Ctenotus atlas.

Fig. S8 Probabilities of assignment to genetic clusters identified by GENELAND.

Table S4 Results from causal modelling of the effect of landscape resistance on genetic distance in Amphibolurus norrisi and Ctenotus atlas.

Table S5 Age and sex structure of Amphibolurus norrisi and Ctenotus atlas at Hincks and Pinkawillinie.

Table S6 Mantel tests for isolation by distance and allelic richness from data simulated under a stable demographic scenario and a disturbed scenario.

Appendix S1 A spreadsheet containing the sample information, genotype data and input files for analyses.

\section{Figure legends}

Fig. 1 Samples from Amphibolurus norrisi and Ctenotus atlas were collected from 38 sites across fire mosaics in four conservation reserves on the Eyre Peninsula, South Australia. At Heggaton, we used both spatial and temporal sampling strategies as similar sample sizes were collected across the landscape before $(A$. norrisi $=20 ; C$. atlas $=21)$ and after $(A$. norrisi $=21 ; C$. atlas $=22)$ prescribed fires in April 2006. At the other three reserves, samples were collected after the most recent fire (Hincks: Dec 2006; Pinkawillinie: Dec 2005; Munyaroo: Oct 1990), except at two sites each at Hincks and Pinkawillinie where samples were collected before and after fires (before/after sample sizes indicated as $\mathrm{N} / \mathrm{N})$.

This article is protected by copyright. All rights reserved. 
Fig. 2 The effect of time since fire on allelic richness in (A) Ctenotus atlas $(P=0.037)$ and $(B)$

Amphibolurus norrisi $(P=0.003)$ and $(C)$ the effect of reserve on allelic richness in $A$. norrisi $(P<$

0.001). All results are from a standardised sample size of five individuals. Model estimates are shown over the data in $\mathrm{A}$ and $\mathrm{B}$ (open circles $=$ Heggaton; closed circles $=$ Hincks; closed triangles $=$ Munyaroo; open triangles = Pinkawillinie). Error bars are $95 \%$ confidence intervals.

Fig. 3 Probabilities of assignment to genetic clusters identified by GENELAND (each bar represents an individual lizard). Plots are shown only for data sets in which genetic differentiation was detected. (A) Differentiation between Hincks at the other reserves was evident for C. atlas and (B) a distinct cluster was formed by N3 and N4 within Heggaton for A. norrisi. For Heggaton, the site name and year of last fire is shown below the bars and whether samples were collected (b) before or (a) after the prescribed fires is shown above the bars.

Table 1 Analytical techniques used to answer our four research questions

\begin{tabular}{|c|c|c|}
\hline Method & Data set & Level \\
\hline \multicolumn{3}{|c|}{$\begin{array}{l}\text { Question 1. Does spatial variation in fire, topography and population density influence gene flow } \\
\text { and genetic diversity? }\end{array}$} \\
\hline $\begin{array}{l}\text { Linear-mixed models of time since fire } \\
\text { effects on allelic richness }\end{array}$ & Sample sites with $\geq 5$ individuals & Population \\
\hline $\begin{array}{l}\text { Linear-mixed models of time since fire } \\
\text { effects on individual heterozygosity }\end{array}$ & All samples & Individual \\
\hline STRUCTURE & All samples & Individual \\
\hline GENELAND & All samples & Individual \\
\hline $\begin{array}{l}\text { Simple and partial Mantel tests of the } \\
\text { effects of landscape resistance on } \\
\text { genetic distance }\end{array}$ & $\begin{array}{l}\text { All samples except pre-2005/2006 } \\
\text { fire samples at Hincks and } \\
\text { Pinkawillinie }\end{array}$ & Individual \\
\hline \multicolumn{3}{|c|}{ Question 2. Is there an immediate, temporal effect of fire in the landscape on genetic structure? } \\
\hline $\begin{array}{l}\text { Simple and partial Mantel tests of the } \\
\text { effects of landscape resistance on } \\
\text { genetic distance }\end{array}$ & $\begin{array}{l}\text { Heggaton samples pre- and post- } \\
\text { fire }\end{array}$ & Individual \\
\hline
\end{tabular}

This article is protected by copyright. All rights reserved. 
Question 3. Is post-fire re-establishment facilitated by survivors, or by immigration?

STRUCTURE analysis on samples within the overall sample and on each site separately
Five sites (two at Hincks, two at Individual

Pinkawillinie and one at Heggaton)

where samples were collected

before and after fires that occurred

during the study

Question 4. Can affects of fire on genetic diversity be explained by differences in demographic attributes?

Generalised linear mixed models of time since fire effects on population age structure and sex ratios

Simple Mantel tests of isolation by distance in adult males and adult females separately (sex-biased dispersal)

EASYPOP simulations of genetic data for stable and disturbed $A$. norrisi populations
'Grid' sites at Hincks and

Population

Pinkawillinie (Table S1) where age and sex were recorded

'Grid' sites at Hincks and Individual

Pinkawillinie (Table S1) where age and sex were recorded

Simulated microsatellite data
Population

Table 2 Five spatial models of landscape resistance based on features that could affect gene flow in Amphibolurus norrisi and Ctenotus atlas

\begin{tabular}{lll}
\hline $\begin{array}{l}\text { Spatial } \\
\text { model }\end{array}$ & Grid cell values & Potential ecological importance \\
\hline $\begin{array}{l}\text { Isolation by } \\
\text { distance }\end{array}$ & 1 & $\begin{array}{l}\text { Genetic distance can increase with geographic } \\
\text { distance (Wright 1943). }\end{array}$ \\
\hline $\begin{array}{l}\text { Sand dune } \\
\text { topography }\end{array}$ & Metres above & smphibolurus norrisi has been recorded more \\
& & $\begin{array}{l}\text { commonly on dunes than swales (South 2010) and C. } \\
\text { atlas depends on Triodia spp. which occur on deep } \\
\text { sands (Pianka 1972). Gene flow may be inhibited or } \\
\text { promoted by sand dunes if the dunes affect their } \\
\text { dispersal ability or population density. }\end{array}$ \\
& & Marked changes in vegetation structure occur with \\
Time since & Number of & TSF at our study sites (Smith et al. 2012) and habitat \\
& years since & structure can affect dispersal and population density \\
& most recent & in lizards (Berry et al. 2005; Templeton et al. 2011). \\
\hline
\end{tabular}

This article is protected by copyright. All rights reserved. 


\begin{tabular}{|c|c|c|}
\hline & & $\begin{array}{l}\text { This model test whether gene flow is affected by TSF } \\
\text { in a linear way. }\end{array}$ \\
\hline $\begin{array}{l}\text { Population } \\
\text { density }\end{array}$ & $\begin{array}{l}\text { Mean no. } \\
\text { captures } \\
\text { predicted from } \\
\text { TSF (Smith et } \\
\text { al. 2013) }\end{array}$ & $\begin{array}{l}\text { Habitat suitability for lizards does not always change } \\
\text { linearly with TSF (Nimmo et al. 2012; Smith et al. } \\
\text { 2013). Dispersal through unsuitable habitat may be } \\
\text { inhibited (Prevedello et al. 2010; Shanahan et al. } \\
\text { 2011) or promoted (Driscoll \& Hardy 2005; } \\
\text { Schtickzelle et al. 2007) and increased population } \\
\text { density can positively or negatively affect gene flow } \\
\text { (Robinet et al. 2008; Stephens et al. 1999). }\end{array}$ \\
\hline $\begin{array}{l}\text { Fire } \\
\text { frequency }\end{array}$ & $\begin{array}{l}\text { Number of fires } \\
\text { since } 1953 \text { (0- } \\
5)\end{array}$ & $\begin{array}{l}\text { Fire can have cumulative effects on animal } \\
\text { populations (Lindenmayer et al. 2008) either through } \\
\text { demographic impacts of repeated burning (Westgate } \\
\text { et al. 2012) or changes in habitat structure (Pausas \& } \\
\text { Lloret 2007). }\end{array}$ \\
\hline
\end{tabular}

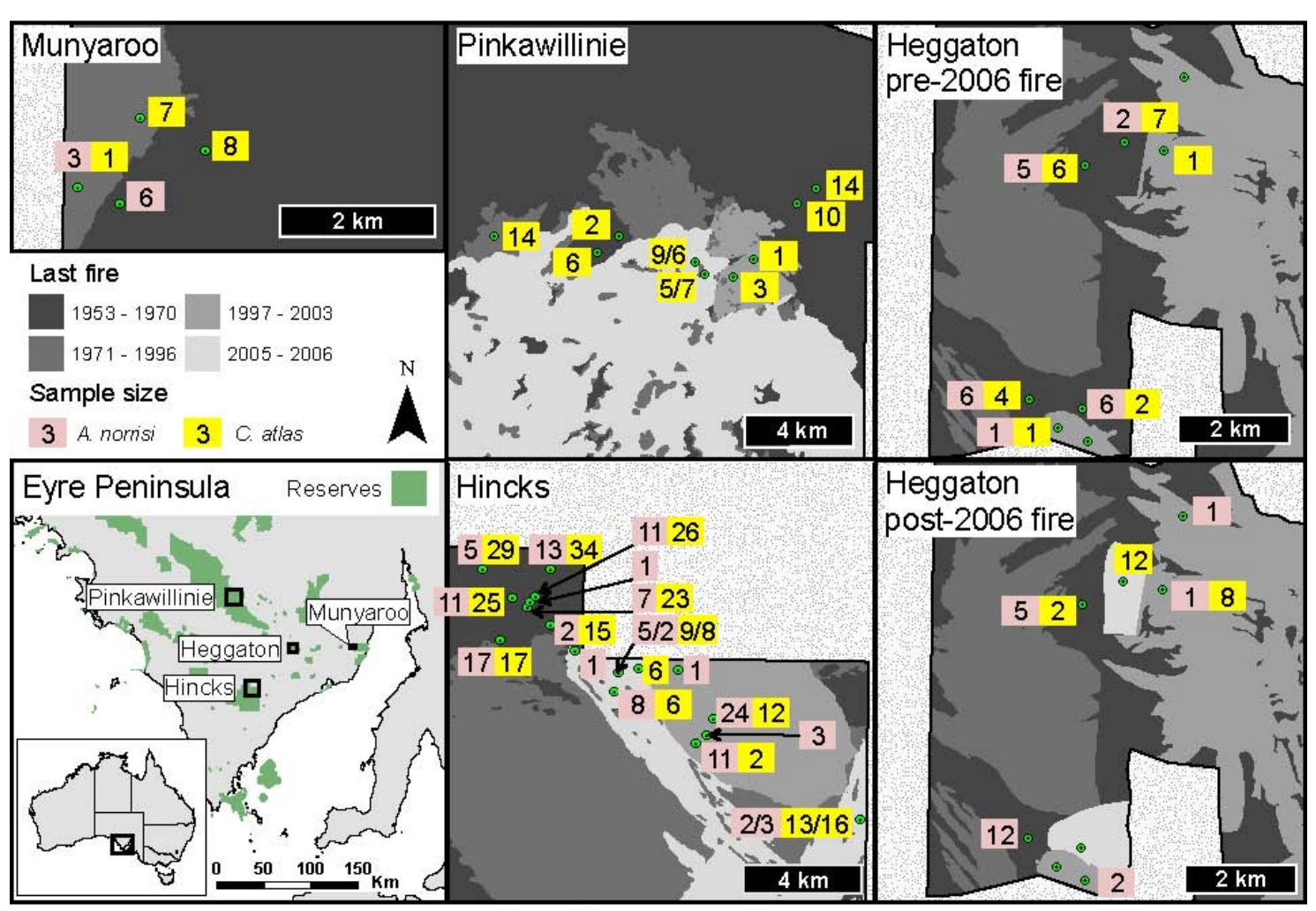

This article is protected by copyright. All rights reserved. 

A
C. atlas
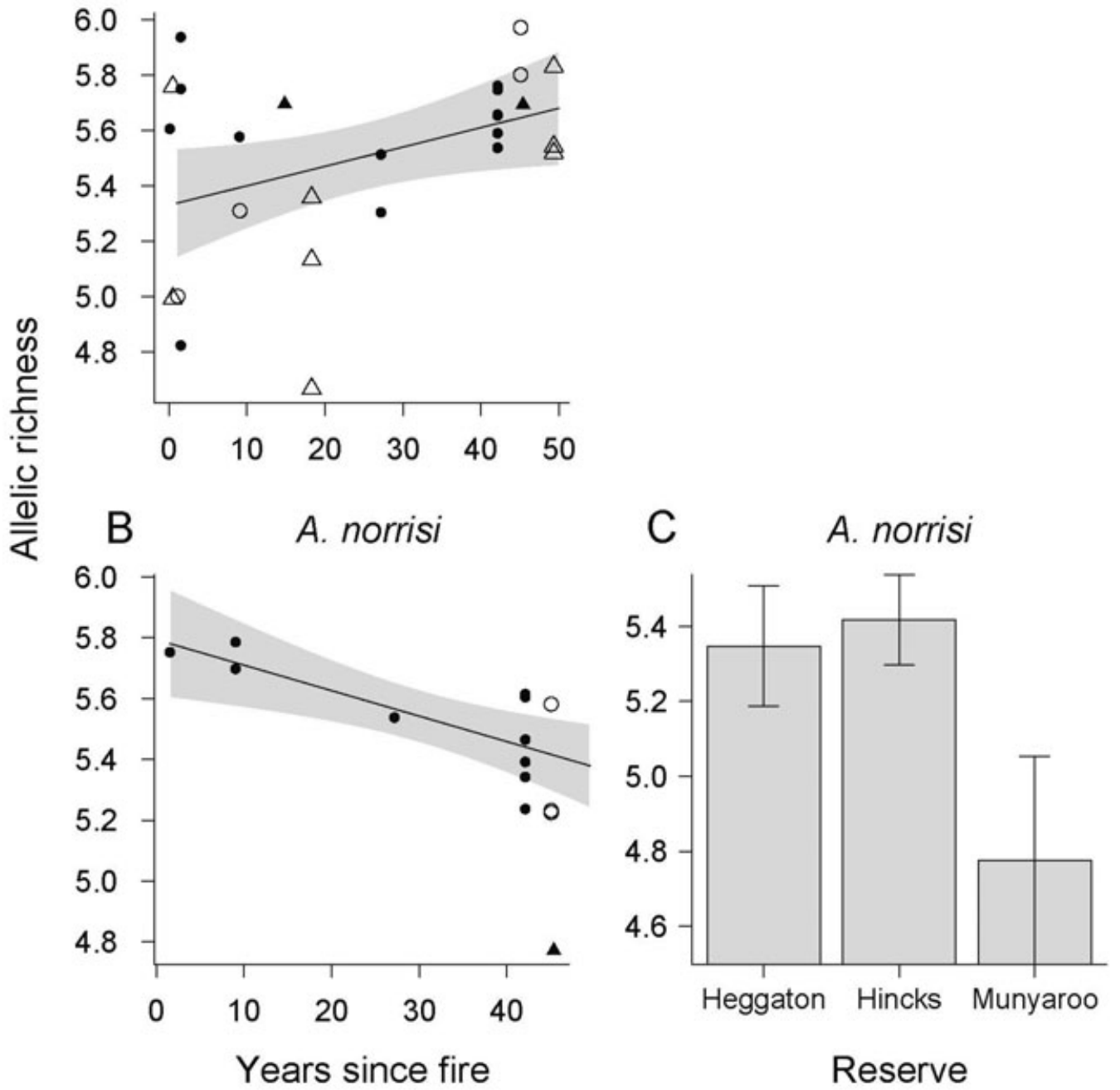

This article is protected by copyright. All rights reserved. 


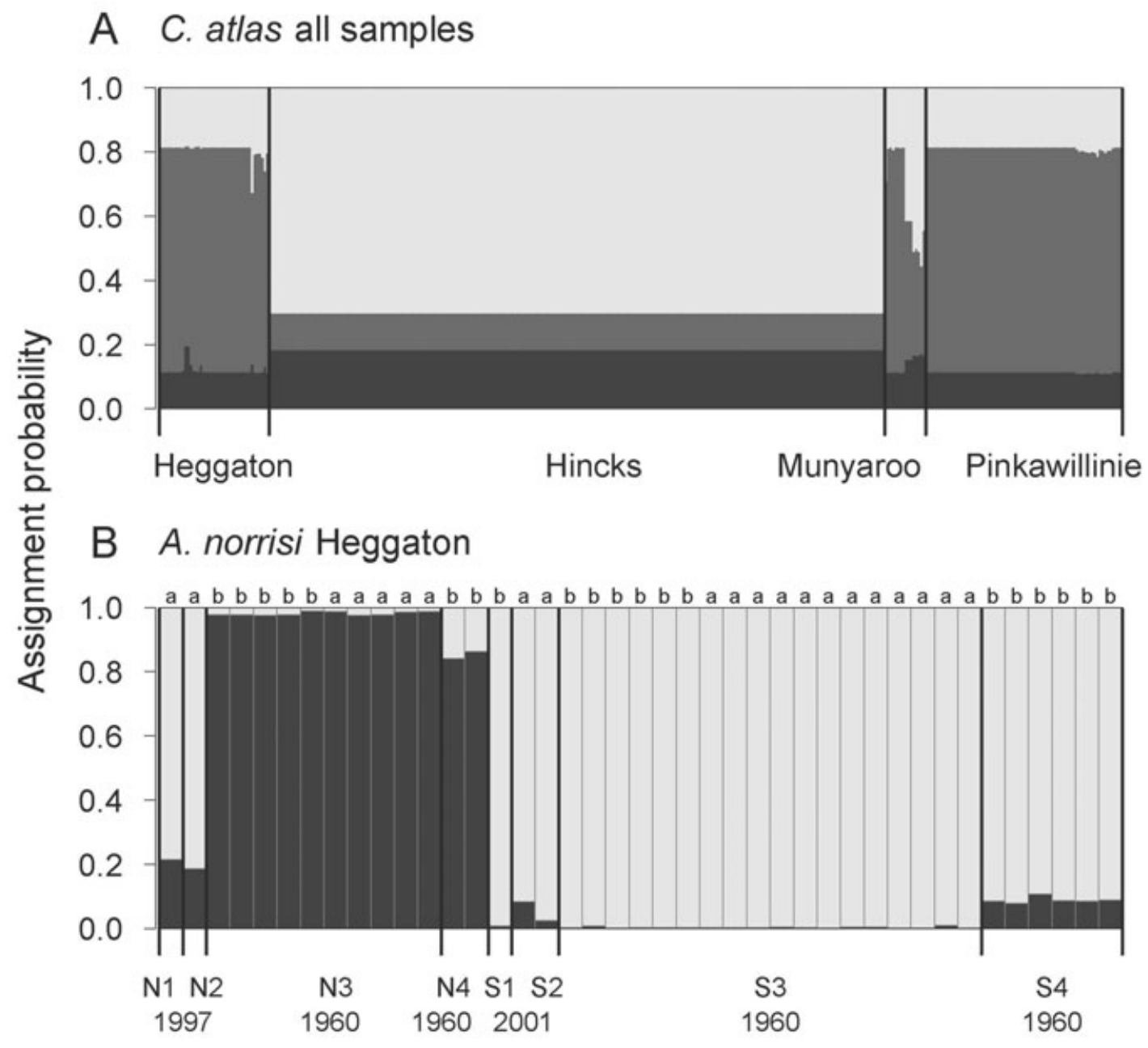

This article is protected by copyright. All rights reserved. 